\title{
FACTORS INFLUENCING SALARIES OF PRE-SCHOOL TEACHERS IN LATVIA REGIONS
}

\author{
Anda Grinfelde ${ }^{1}$, Dr.oec.; Inga Vanaga ${ }^{2}$, PhD student; Liga Paula ${ }^{3}$, Dr.sc.soc. \\ 1,3 Latvia University of Life Sciences and Technologies; '2University of Latvia; Latvian Trade Union of Education \\ and Science Employees
}

\begin{abstract}
Educators are the most important factor for children's well-being, learning and development outcomes especially at pre-school level. The problem of an unequal workload of pre-school teachers and the corresponding salary in regions of Latvia has defined the research aim, which is to identify problems in ensuring equal opportunities in pre-school teachers' workload and average salaries in the regions of Latvia, as well as to develop proposals to reduce inequalities. The paper reflects the results of a study on inequalities in the payroll and monthly salaries of pre-school teachers. The research data were obtained from interviews with members of 12 local trade unions of Latvian Trade Union of Education and Science Employees throughout Latvia and quantitative survey in 119 municipalities. The survey of local governments was conducted in Autumn 2019 to find out the average workload and monthly salary rate of pre-school teachers in municipalities. At the second stage of the research, chairpersons of the local trade unions were interviewed in order to collect suggestions for improving the pay model for pre-school teachers. Results show that the salary of pre-school teachers depends on local political decisions of the municipalities on the organization of pre-school work, the subsequent workload and the monthly salary rate determined by each municipality. Pre-school teachers have a limited right to equal pay for work of equal value in different regions of Latvia. According to a survey of local trade unions, all respondents believe that funding for pre-school teachers should be provided by the state budget in order to prevent local governments from setting different monthly salary rates.
\end{abstract}

Key words: regions, inequality, pre-school teachers, salary, teacher workload.

JEL code: R23, K31

\section{Introduction}

Pre-school education is the first stage of education playing an important role in individual's further education, his/her competitiveness in the labour market, socialization according to the values and norms of society. Highly motivated professionals need to be employed in pre-school education; therefore, a strategic approach is needed to improve the quality of work and motivation of pre-school teachers (OECD, 2018). The role of human capital, including education, in the development of society is difficult to quantify and is often overlooked in economic calculations. Recommendations of the European Commission on high quality early childhood education and care systems sets out the rationale that the return on investment at an early stage is the highest of all education stages. Early childhood education can be an effective means of achieving an equal level of education for all children. In particular, the work of early childhood education and care professionals has a lasting impact on children's lives. Spending on early childhood education and care is an early investment in human capital. To put it differently, "the highest social gains come from investing during early years" (Council of Europe Development Bank, 2017, p.1). Quality considerations must be given priority in policy measures and reforms. In order to play their professional role in supporting children and their families, pre-school education and care staff need sophisticated knowledge and competencies as well as a deep understanding of child development and knowledge of early childhood education (Priekslikums Padomes...). Educators are the most important factor for children's well-being, learning and development outcomes. Therefore, the quality of work of staff is considered to be an essential component of the quality of education.

\footnotetext{
${ }^{1}$ Anda.Grinfelde@llu.Iv, +37129265476

2 inga.vanaga@lizda.Iv, +371 25998994

${ }^{3}$ Liga.Paula@llu.Iv, +37126321667
} 
The issue of income inequality is more broadly addressed in the European Pillar of Social Rights (The European Pillar...), presented by the European Commission in April 2017. The third principle of the pillar is that everyone has the right to equal opportunities. Out of the 14 core indicators included in the accompanying social scoreboard, one relates directly to income inequality, while several others relate to policies closely linked to combating the rise in income inequality and equal opportunities (Nevienlidzibas noversana, 2016). The European Commission notes that inequality is a multidimensional problem. Although inequality can be measured in many different dimensions, the two basic concepts are inequality of outcomes (distribution of income and resources) and inequality of opportunity.

Aspects of inequality between teachers in pre-school education encompass both inequality in outcomes and opportunities. This problem in Latvia has been raised for several years and no research has been carried out on the comparison of the workload of pre-school teachers and the corresponding salary in regions of Latvia to find out which regions concentrate pre-schools where the teachers receive higher and lower average monthly wages. Therefore, the aim of the study is to identify problems in ensuring equal opportunities in pre-school teachers' workload and average wages in the regions of Latvia, as well as to develop proposals to reduce inequalities. The article reflects the results of a study on inequalities in the payroll and monthly wages of preschool teachers. To achieve the aim of the research, the following tasks were set: 1) to conceptualize the factors influencing the wages of pre-school teachers in the context of inequality; 2) to investigate the workload and monthly salary rate of pre-school teachers in Latvian municipalities and comparisons by region; and 3 ) to develop proposals for reducing inequalities among pre-school teachers in different regions and regions of Latvia.

\section{Research results and discussion \\ 1. Research methodology}

The research was carried out to identify problems in ensuring equal opportunities in the workload and average wages of pre-school teachers in the regions of Latvia, therefore the research object is 119 municipalities of Latvia, of which 110 are rural municipalities and 9 cities. In order to compare the average workload and the monthly salary rate in municipalities and statistical regions of the country, municipalities are structured according to one of the six regions in which they are located (Figure 1).

In Latvia, 11.4 thousand of teachers in 634 pre-school establishments provide education for 99.2 thousand of children in age 1.5 to 6 years. The authors in the paper focus on the factors influencing wages for the teachers working with 1.5 to 4 years old children as the wages for this teacher group are influenced by the possibilities of municipal funding and local political decisions. The research data for the paper was obtained from interviews with representatives of 12 local trade unions of Latvian Trade Union of Education and Science Employees and 119 municipalities. Quantitative survey of local governments was conducted from September 30, 2019 to November 5, 2019 to find out the average workload and monthly wage rate of preschool teachers in municipalities. At the second stage of the research, interviews with the chairpersons of the local trade unions was conducted from November 20, 2019 to January 15, 2020, to collect suggestions for improving the pay model for preschool teachers. Information about the workload and salary rate was processed using EXCEL, whereas proposals for improving the model of pay for pre-school teachers were processed by using content analysis, identifying the most frequently made proposals. 


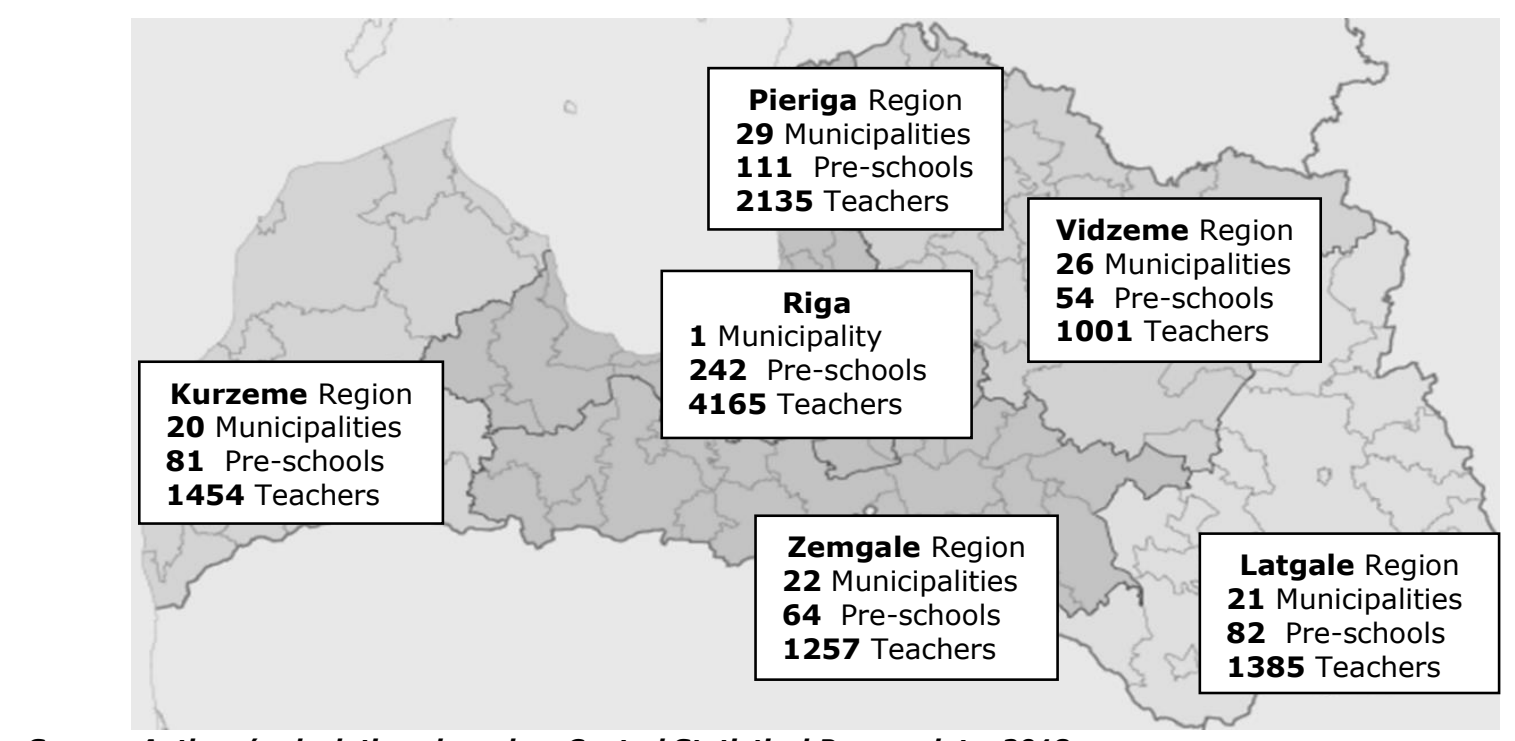

Source: Authors' calculations based on Central Statistical Bureau data, 2018

Fig. 1. Number of municipalities, pre-schools and teachers by statistical region

\section{Regional disparities: analysis of the research results}

In Latvia, according to the Education Law, pre-school education is provided to children from 1.5 years of age, but the availability of this service and the involvement of teachers depend on the priorities and financial resources of each municipality. Pre-school teachers who work with children aged $1.5-4$ are paid by local governments from their own budget, while salaries of teachers who work with children of pre-school age (5-6 years) are paid from the state budget (Izglitibas likums...). Although in Latvia all teachers have the same basic education (qualification) requirements when working with children (Noteikumi par pedagogiem ..., 2018), regulations of the Cabinet of Ministers on the workload and wages of pre-school teachers (Pedagogu darba samaksas noteikumi, 2016) include inequalities: the minimum wage rate is the same for all teachers, while the workload for preschool teachers is significantly higher than for other teachers.

Reducing inequalities and raising the prestige of teaching profession are important subjects of debate in the European Union and in Latvia. Achieving equal opportunities in equal pay for work of equal value and responsibility in the education sector is essential. No matter in which municipality or region the pre-school teacher does works, it should be equal in terms of workload and wages throughout Latvia and compared to other teachers. According to the Education Development Guidelines 2014-2020, the average wage (gross) of education and training employees should be equal to the average at national level in 2020 (Izglitibas attistibas...).

Despite the fact that the average monthly salary in the education sector is increasing every year in both the country and its regions (Figure 2), there is still a significant gap between salaries of those who work in education sector and the average salary in the country. In 2019, the gap reached 210 EUR (Figure 3). 


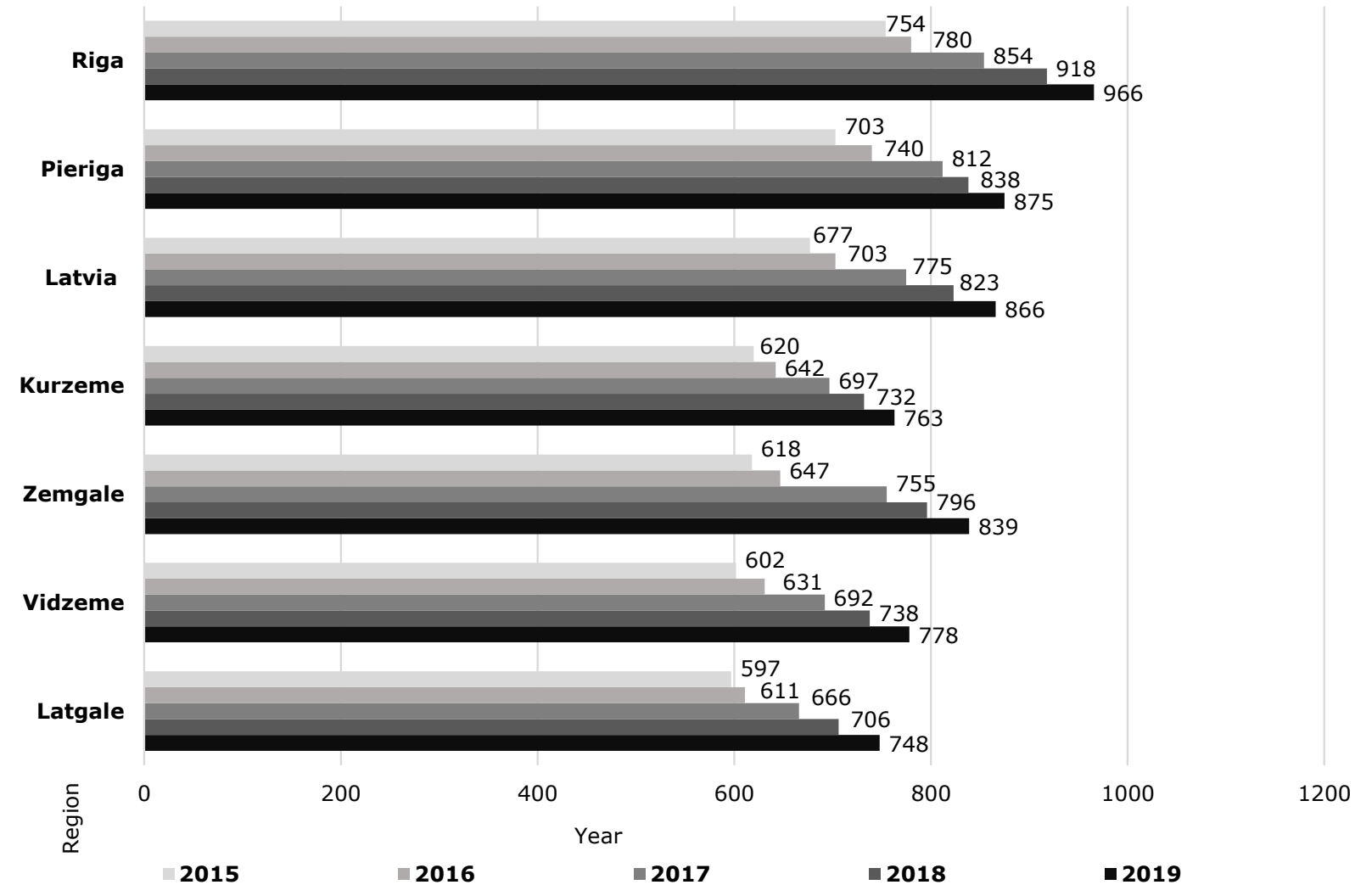

Source: Authors' calculations based on the Central Statistical Bureau data, 2019

Fig. 2. Average monthly gross wages in education sector by regions in 2015-2019, EUR

Comparing the average wages of those working in the education sector in the regions, the biggest difference in the last five years is between teachers in Riga and Latgale (Figure 2). As a result, in regions with lower average teachers' salary there is a smaller difference between the average wage in the country and the average wage in the education sector (e.g. Latgale 3.00 EUR) than in regions with higher average wages, e.g. the gap in Riga is 240.00 EUR (Figure 3.).

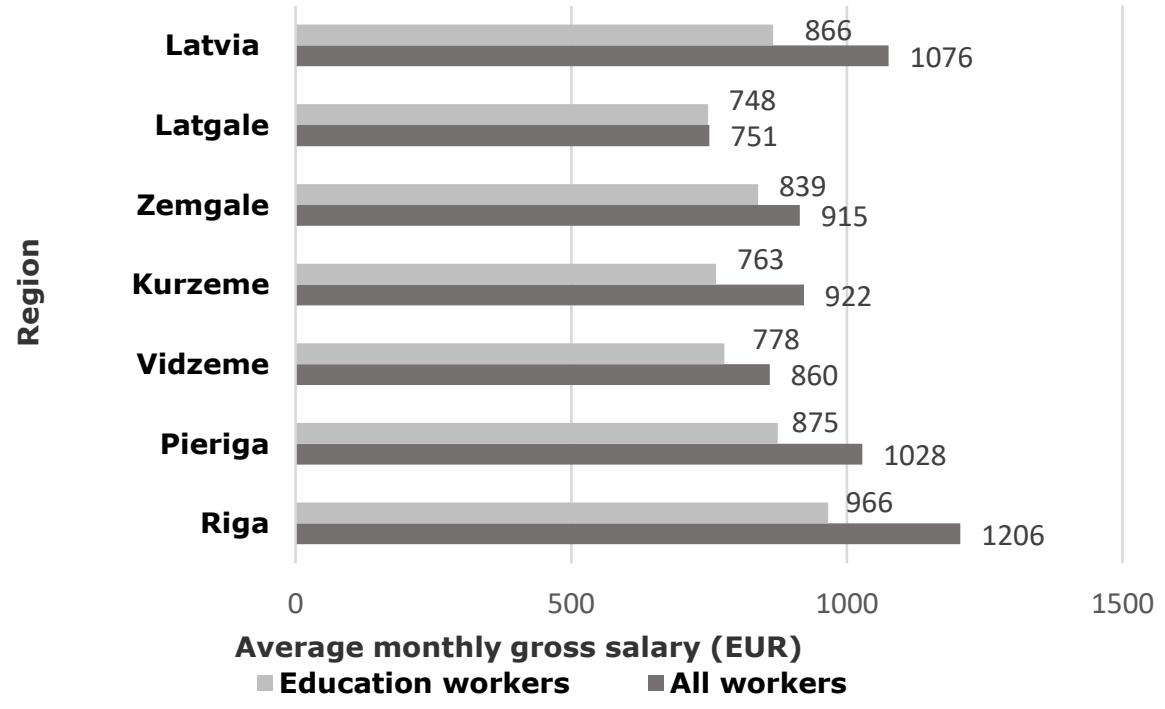

Source: Authors' calculations based on the Central Statistical Bureau data, 2019

Fig. 3. Average monthly gross wages in statistical regions of Latvia in 2019, EUR

The task No 127 of the Government Action Plan (Par valdibas ricibas...) aims to further increase the remuneration of teaching and academic staff including preschool teachers, and to improve the remuneration model. This is due to the fact that preschool teachers are in an unequal position compared to other teachers. Pre-school teachers are currently required to work 40 hours a week, 
including 36 hours with children and 4 hours for preparation of classes, while workload of other teachers is 30 hours a week, including lessons, optional teaching activities, individual and group work, etc. The nationally defined minimum wage for all teachers is EUR 750 per month, but due to the difference in working hours, pre-school teachers may not receive less than 4.69 EUR per hour, but other teachers - not less than 6.25 EUR per hour. Municipalities have different patterns of teacher work load organization in preschools. It also affects the amount of workload of pre-school teachers in regions, for example, 50-60 \% of municipalities in Pieriga, Vidzeme and Zemgale regions provide full-time work for teachers who work with 1.5-4 years old children, whereas only $14 \%$ of Latgale municipalities and $30 \%$ of Kurzeme municipalities can afford this (Table 1).

Table 1

\section{Number of municipalities in Latvia where preschool teachers work full-time,} October 2019

\begin{tabular}{|l|c|c|c|c|}
\hline \multirow{2}{*}{ Region } & \multicolumn{2}{|c|}{$\mathbf{1 . 5}$ years old children } & \multicolumn{2}{c|}{$\mathbf{5}$ - $\mathbf{~ y e a r s ~ o l d ~ c h i l d r e n ~}$} \\
\cline { 2 - 5 } & $\begin{array}{c}\text { Number of } \\
\text { municipalities }\end{array}$ & $\mathbf{\%}$ & $\begin{array}{c}\text { Number of } \\
\text { municipalities }\end{array}$ & $\mathbf{\%}$ \\
\hline Riga city & 1 & 100 & 1 & 100 \\
\hline Pieriga & 15 & 52 & 16 & 55 \\
\hline Vidzeme & 16 & 62 & 16 & 62 \\
\hline Kurzeme & 6 & 30 & 7 & 35 \\
\hline Zemgale & 14 & 64 & 17 & 77 \\
\hline Latgale & 3 & 14 & 5 & 24 \\
\hline Latvia & $\mathbf{4 8}$ & $\mathbf{4 0}$ & $\mathbf{2 9}$ & $\mathbf{2 4}$ \\
\hline
\end{tabular}

Source: Authors' calculations based on LIZDA survey data

The workload of pre-school teachers is the most important factor influencing wages. If there is a difference in the amount of workload, there is also a difference in the average monthly wage in the regions (Table A2). Comparing the average monthly salary rate of pre-school teachers in municipalities, it can be concluded that in Pieriga region the salary rate for pre-school teachers in municipalities is much higher than officially defined minimum (750 EUR) reaching up to 1006 EUR per month. In Latgale region, on the other hand, only two municipalities have higher wage rates than minimum for pre-school teachers. An even more negative tendency is due to the fact that municipalities are unable to provide full-time workload for teachers and as a result, in Latgale region, unlike Pieriga region, the average monthly salary is below the minimum wage in almost all municipalities. Only in three municipalities it has reached 750 EUR. The salary of pre-school teachers depends on the local political decisions of the municipality on the organization of work; the subsequent workload and the monthly salary rate will be determined by each municipality. Preschool teachers have a limited right to equal pay for work of equal value in different regions of Latvia. 


\section{Distribution of municipalities according to pedagogical rate and average monthly salary of preschool teachers in the regions of Latvia, October 2019, $n=118$}

\begin{tabular}{|c|c|c|c|c|c|c|c|c|c|c|}
\hline \multirow[b]{2}{*}{$\begin{array}{c}\text { Income level } \\
\text { (EUR) }\end{array}$} & \multicolumn{2}{|c|}{ Pieriga } & \multicolumn{2}{|c|}{ Vidzeme } & \multicolumn{2}{|c|}{ Kurzeme } & \multicolumn{2}{|c|}{ Zemgale } & \multicolumn{2}{|c|}{ Latgale } \\
\hline & Rate & $\begin{array}{c}\text { Average } \\
\text { salary }\end{array}$ & Rate & $\begin{array}{c}\text { Average } \\
\text { salary }\end{array}$ & Rate & $\begin{array}{c}\text { Average } \\
\text { salary }\end{array}$ & Rate & $\begin{array}{c}\text { Average } \\
\text { salary }\end{array}$ & Rate & $\begin{array}{c}\text { Average } \\
\text { salary }\end{array}$ \\
\hline $351-399$ & 0 & 0 & 0 & 0 & 0 & 0 & 0 & 1 & 0 & 1 \\
\hline $400-449$ & 0 & 0 & 0 & 1 & 0 & 1 & 0 & 2 & 0 & 1 \\
\hline $450-499$ & 0 & 1 & 0 & 0 & 0 & 0 & 0 & 0 & 0 & 0 \\
\hline $500-549$ & 0 & 1 & 0 & 1 & 0 & 0 & 0 & 0 & 0 & 0 \\
\hline $550-599$ & 0 & 0 & 0 & 0 & 0 & 1 & 0 & 2 & 0 & 4 \\
\hline $600-649$ & 0 & 2 & 0 & 0 & 0 & 6 & 0 & 1 & 0 & 4 \\
\hline $650-699$ & 0 & 2 & 0 & 3 & 0 & 4 & 0 & 7 & 0 & 5 \\
\hline $700-749$ & 0 & 2 & 0 & 5 & 0 & 2 & 0 & 0 & 0 & 3 \\
\hline $\begin{array}{l}\text { In total } \\
(351-749)\end{array}$ & 0 & 8 & 0 & 10 & 0 & 14 & 0 & 13 & $\mathbf{0}$ & 18 \\
\hline 750 (minimum) & 11 & 5 & 24 & 16 & 19 & 6 & 20 & 8 & 19 & 3 \\
\hline $751-799$ & 3 & 6 & 2 & 0 & 1 & 0 & 0 & 1 & 1 & 0 \\
\hline $800-849$ & 6 & 5 & 0 & 0 & 0 & 0 & 2 & 0 & 1 & 0 \\
\hline $850-899$ & 2 & 0 & 0 & 0 & 0 & 0 & 0 & 0 & 0 & 0 \\
\hline $900-949$ & 5 & 4 & 0 & 0 & 0 & 0 & 0 & 0 & 0 & 0 \\
\hline $950-1006$ & 2 & 1 & 0 & 0 & 0 & 0 & 0 & 0 & 0 & 0 \\
\hline $\begin{array}{l}\text { In total } \\
(751-1006)\end{array}$ & 18 & 16 & 2 & $\mathbf{0}$ & 1 & $\mathbf{0}$ & 2 & 1 & 2 & 0 \\
\hline
\end{tabular}

Source: Authors' calculations based on LIZDA survey data

According to a survey of local trade unions, all respondents believe that funding for pre-school teachers should be provided by the state budget in order to prevent local governments from setting different monthly salary rates. The survey allows to conclude that municipalities have different organization of pre-school teachers' work including different limits of working hours of pre-schools, number of children per teacher, planning of teachers' work, different requirements to be at work or to remotely prepare lessons. As a result of the survey, it is proposed to improve the remuneration model for pre-school teachers by reducing the proportion of lessons with children and providing a greater number of hours for class preparation. This is crucially important for the qualitative implementation of the new reform, the competency-based curriculum, which involves the transition from ready-to-use knowledge to meaningful engagement or learning by each child.

The world's most important report on quality of education in OECD member countries and partner countries, "Education at a Glance: OECD Indicators", shows that although Latvia's expenditure on pre-school education as a percentage of gross domestic product is one of the highest in OECD countries, expenditure per child is significantly lower than the OECD average (OECD, 2018). Preschool teachers in Latvia receive three times less salaries than the average in OECD countries. In 2016, pre-school teachers in Latvia earned an average of 10551 EUR per year, the lowest in all OECD countries and partner countries, and well below the OECD average of 31701 EUR (OECD, 2018). With reference to the above, it should be concluded that regarding significant inequalities in pay between pre-school teachers in the OECD countries, it would initially be necessary to eliminate inequalities in the regions of Latvia and achieve equal opportunities for all teachers to work full time and to receive equivalent pay for work with equivalent qualifications. 


\section{Conclusions and recommendations}

1) In Latvia, the salaries of pre-school education teachers are three times lower than the OECD average, but their growth tendency is upward, however, lower than the average salary in Latvia. In regions with higher average monthly wages (in all sectors overall) there is a larger difference compared to the average monthly wage in education.

2) There are regional disparities in the provision of workload for pre-school teachers, leading to marked disparities in average monthly wages. In order to reduce inequalities between regions in the provision of workloads and the corresponding wages for pre-school teachers, the funding of pre-school teachers' salaries should be provided from the state budget.

3) Reduction of inequality in pre-school education institutions requires improvement of the preschool teacher remuneration model by reducing the proportion of hours with students and providing for a greater number of hours for class preparation.

\section{Bibliography}

1. Central Statistical Bureau. Retrieved: http://www.csb.gov.lv/en/dati/data-23959.html Access: 05.03.2020.

2. Council of Europe Development Bank (2017). Educational inequality in Europe: Tackling Inequalities in Europe: The Role of Social Investment. Retrieved: https://coebank.org/media/documents/Part_2-InequalityEducation_lowres.pdf Access: 05.03.2020.

3. Izglitibas attistibas pamatnostadnes 2014. - 2020. gadam. Retrieved: https://m.likumi.lv/doc.php?id=266406 Access: 02.03.2020.

4. Izglitibas likums (1998). Retrieved: https://likumi.Iv/doc.php?id=50759 Access: 05.03.2020.

5. Nevienlidzibas noversana (2016). Eiropas pusgada tematiska faktu lapa. Retrieved: https://ec.europa.eu/info/sites/info/files/file_import/european-semester_thematic factsheet_addressinginequalities_Iv.pdf Access: 21.03.2020.

6. Noteikumi par pedagogiem nepieciesamo izglitibu un profesionalo kvalifikaciju un pedagogu profesionalas kompetences pilnveides kartibu Nr. 569 (2018). Retrieved: https://likumi.lv/ta/id/301572-noteikumi-parpedagogiem-nepieciesamo-izglitibu-un-profesionalo-kvalifikaciju-un-pedagogu-profesionalas-kompetencespilnveides 21.03.2020.

7. OECD (2018). Education at a Glance 2018: OECD Indicators. Paris: OECD Publishing. Retrieved: https://www.oecd-ilibrary.org/education/education-at-a-glance-2019_f8d7880d-en 21.03.2020.

8. Par Valdibas ricibas planu Deklaracijas par Artura Krisjana Karina vadita Ministru kabineta iecereto darbibu istenosanai. Retrieved: https://likumi.Iv/ta/id/306691-par-valdibas-ricibas-planu-deklaracijas-par-arturakrisjana-karina-vadita-ministru-kabineta-iecereto-darbibu-istenosanai Access: 05.03.2020.

9. Pedagogu darba samaksas noteikumi Nr.445 (2016). Retrieved: https://likumi.lv/ta/id/283667-pedagogudarba-samaksas-noteikumi 21.03.2020.

10. Priekslikums Padomes ieteikumam par augstas kvalitates agrinas pirmsskolas izglitibas un aprupes sistemam. Retrieved: https://ec.europa.eu/education/education-in-the-eu/council-recommendation-on-high-qualityearly-childhood-education-and-care-systems_Iv 21.03.2020.

11. The European Pillar of Social Rights in 20 principles. Retrieved: https://ec.europa.eu/commission/priorities/deeper-and-fairer-economic-and-monetary-union/europeanpillar-social-rights/european-pillar-social-rights-20-principles_en Access: 19.03.2020 